\title{
Quantitative Study of Tyrosine Hydroxylase Protein Levels within the Somatic Area of the Rat Locus Coeruleus during Postnatal Development
}

\author{
Laurent Bezin, Dominique Marcel, Colette Rousset, Jean-François Pujol, and Dinah Weissmann \\ Laboratoire de Neuropharmacologie Moléculaire, CNRS-UCBL UMR 105, CERMEP, 69003 Lyon, France
}

To date only global dosages of tyrosine hydroxylase (TH) protein have been realized in the locus coeruleus (LC) without discriminating the enzyme contained in the cell body area from the one in the surrounding neuropil. The preceding immunohistochemical study (Bezin et al., 1994) revealed a dramatic plasticity of the cellular expression of TH in the LC during the postnatal development of the rat. It was therefore necessary to develop a quantitative biochemical approach, strengthened by a great anatomical resolution, to follow the developmental evolution of TH levels exactly in the space containing the coerulean TH-immunoreactive perikarya. In the present work two biochemical parameters necessary for precisely defining the phenotypic characterization of TH expression within the rat $L C$ have been established during the postnatal development at six different stages: postnatal day 4 (PND4), PND10, PND14, PND21, PND30, and PND42. TH tissue concentration and content were precisely determined along the caudorostral extent of the LC within the previously (Bezin et al., 1994) defined spaces delimited by the THcontaining perikarya. TH tissue concentration remained quite stable during the postnatal development. TH quantlty exhibited few age-related variations with a transient peak at PND 10 and followed the same evolution as the volume containing the TH-expressing perikarya. The mean cell contribution to the total quantity of TH measured in the whole LC showed important age-related fluctuations with a dramatic peak at PND10 followed by a drastic decrease until PND21. Such modifications of the steady-state levels of TH in the perikarya of coerulean neurons could be related to temporal requirements of this enzyme in their other cellular compartments such as dendrites or terminals, and/or alterations of the synthesis of the protein.

[Key words: tyrosine hydroxylase, locus coeruleus, postnatal development, somatic area, quantitative radioautography, plasticity]

The tyrosine hydroxylase [TH: tyrosine 3-monooxygenase, L-tyrosine, tetrahydropteridine: oxygen oxidoreductase (3-hydroxylating), EC 1.14.16.2] is the rate-limiting enzyme in the catecholamine (CA) biosynthesis pathway (Nagatsu et al., 1964;

\footnotetext{
Received Dec. 14, 1993; revised May 2, 1994; accepted June 2, 1994.

This work was supported by grants from CNRS-UMR 105, Université Claude Bernard Lyon I, DRET (509210) and MRT (91127).

Correspondence should be addressed to Laurent Bezin, CNRS-UCBL UMR 105, CERMEP 59, Bd Pinel, 69003 Lyon, France.

Copyright (C) 1994 Society for Neuroscience $0270-6474 / 94 / 147502-09 \$ 05.00 / 0$
}

Levitt et al., 1965). In the preceding companion study (Bezin et al., 1994) we aimed to characterize the spatiotemporal sequences of events during the postnatal ontogeny that led to the organization of cells expressing $\mathrm{TH}$ protein in the adult rat locus coeruleus (LC) observed at steady-state conditions. We then quantitatively reconstructed the mean limit of the topological space of the LC delineated by the TH expressing perikarya and enumerated these perikarya. We have also determined the volume delimited by the TH-positive cell bodies and the density of these perikarya. These parameters were examined along the caudorostral extent of the structure at six different postnatal stages between postnatal day 4 (PND4) and PND42. This study revealed invariant and variant cellular phenotypic characteristics of TH expression during postnatal ontogeny. The volume of the total LC delineated by the TH-expressing cells was stable during the period considered. However, a deep topological reorganization of the coeruleal TH-expressing perikarya occurred until the third postnatal week and a plasticity of TH expression was demonstrated by transient enhancements of the number of TH-containing cells at PND14 and PND21. From the quantitative reconstructions of the cellular topological space of the LC of PND14, PND21, and PND42 rats, three organized subsets of "quiescent" neurons, which would transiently express TH protein trait, have been suggested in different localizations of the structure.

We intended in the present work to precisely define two more phenotypic characteristics of TH protein expression in the LC. So, we have accurately established the tissue concentration and the quantity of this protein. We also proposed to estimate for each development stage the mcan cell contribution to the TH level evaluated in the somatic area of the total LC. Therefore, the quantitative biochemical evaluations of the TH tissue concentration and the TH quantity were performed with precision along the caudorostral extent of the LC, exactly within the topological space delineated by the TH-expressing cell bodies, at the six postnatal stages selected in the earlier study: PND4, PND10, PND14, PND21, PND30, and PND42.

\section{Material and Methods}

Animal and tissue preparation. All experiments were carried out in accordance with the French (87-848, Ministère de l'Agriculture et de la Forêt) and European Community (86-609, EEC) guidelines for care of laboratory animals and were approved by the regional ethical animal use committee.

OFA male rats (Iffa-Credo, Lyon, France) were examined at different postnatal stages to evaluate the tissue concentration and the quantity of TH within the somatic area of the LC: postnatal days 4 (PND4), PND10, PND14, PND21, PND30, and PND42. The day of birth was taken as PND0. Distortions between animals belonging to a same age 


\begin{tabular}{|c|c|c|c|c|c|c|}
\hline $\begin{array}{l}\text { Postnatal } \\
\text { age }\end{array}$ & $\begin{array}{l}\text { PND4 } \\
(n=6)\end{array}$ & $\begin{array}{l}\text { PND10 } \\
(n=6)\end{array}$ & $\begin{array}{l}\text { PND14 } \\
(n=5)\end{array}$ & $\begin{array}{l}\text { PND21 } \\
(n=6)\end{array}$ & $\begin{array}{l}\text { PND30 } \\
(n=6)\end{array}$ & $\begin{array}{l}\text { PND42 } \\
(n=6)\end{array}$ \\
\hline Body weight & 10.31 & 25.75 & 30.48 & 42.19 & 92.13 & 224.00 \\
\hline$(\mathrm{gm})^{a}$ & \pm 0.12 & \pm 0.19 & \pm 0.4 & \pm 0.59 & \pm 0.79 & \pm 1.66 \\
\hline Freezing time & $30 \mathrm{sec}$ & $40 \mathrm{sec}$ & $50 \mathrm{sec}$ & $1 \mathrm{~min}$ & $1 \mathrm{~min}$ & $1 \mathrm{~min}$ \\
\hline
\end{tabular}

${ }^{a}$ Mean and SEM obtained for $n$ animals.

group had been avoided by recording the body weight of the pups (Table 1). For rats aged from PND4 to PND14, litters arrived to the animalery with a foster mother $3 \mathrm{~d}$ before experiments. Older rats were kept 1 week in the animalery under a $12: 12 \mathrm{hr}$ dark/light cycle at $21^{\circ} \mathrm{C}$ with food and water ad libitum before experiments.

After decapitation, the brains were rapidly removed from the skull and frozen by immersion in isopentane liquid. Freezing time and temperature are reported for each age group in Table 1. Brains were stored at $-80^{\circ} \mathrm{C}$ until further use.

Two or three adjacent frontal cryostat-cut sections ( $10 \mu \mathrm{m}$ thick) were selected at $80 \mu \mathrm{m}$ intervals along the caudorostral extent of the LC. The first slice was directly collected onto nitrocellulose filter (Millipore HAHY) as described in previous studies (Weissmann et al., 1989) to perform TH radioautographic dosage. At PND14-PND42, the second slice was collected onto $1 \%$ gelatin (Sigma)-coated glass slides and processed for TH immunohistochemistry (Bezin et al., 1994). The third slice (at PND14 through PND42) or the second slice (at PND4 and PND10) was collected onto a glass slice and was stained with cresyl violet for histological reference.

TH immunoradioautography. The calibration of the radioimmunochemical labeling of the TH protein was made using two different solutions of adult rat adrenal gland and adult rat cerebellum prepared as described in previous studies (Debure et al., 1992) by homogenizing $\left(20 \%\right.$ w/v) the fresh tissues in a $5 \mathrm{~mm}$ phosphate buffer $\left(\mathrm{K}_{2} \mathrm{HPO}_{4}, \mathrm{KH}_{2} \mathrm{PO}_{4}\right.$, $\mathrm{pH} 6.0$ ) containing $0.2 \%$ Triton $\mathrm{X}-100$. From these two solutions, a scale of seven TH protein standards was prepared by diluting in series the TH protein contained in the solution of adrenal gland with the solution of cerebellum (containing very low concentration of TH protein) to keep constant the total protein concentration. The ratios of dilution for each TH protein standard were, finally, 1, 1:2, 1:4, 1:8, $1: 16,1: 32$, and 1:64. Aliquots of $1 \mu 1$ of each standard and cerebellum solution were directly deposited onto nitrocellulose filters (Millipore HAHY).

After saturation of the nitrocellulose filters (containing transfers of standards or tissue sections) in a Tris-HCl-buffered saline solution (TBS, $50 \mathrm{~mm}, \mathrm{pH} 7.4)$ containing $1 \%(\mathrm{w} / \mathrm{v})$ bovine serum albumine (BSA fraction $\mathrm{V}$, Boehringer) for $45 \mathrm{~min}$, the filters were then incubated for
$18 \mathrm{hr}$ with TH mouse monoclonal antibody ( $40 \mu \mathrm{g} / \mathrm{ml}$; Boehringer) 1:4000 diluted in a solution of TBS/1\% BSA or with TH antibody-free buffer for blanks. This concentration of antibody was selected as the lowest saturating all the antigenic sites in rat brain tissue (Debure et al., 1992). After washing, each time $10 \mathrm{~min}$, once in TBS/1\% BSA, and twice in TBS, the filters have been incubated for $2 \mathrm{hr}$ with ${ }^{125} \mathrm{I}$-labeled protein $\mathrm{A}$ (Amersham, S.A.; $30 \mathrm{mCi} / \mathrm{mg} ; 50 \mathrm{nCi} / \mathrm{ml}$ ) prepared in a TBS/ $1 \%$ BSA solution and successively rinsed for 10 min each time in TBS/ $1 \%$ BSA, TBS, TBS $500 \mathrm{~mm}$, and finally briefly in distilled $\mathrm{H}_{2} \mathrm{O}$, and then dried. The immunoradiolabeled filters were then applied to ${ }^{3} \mathrm{H}$ sensitive hyperfilm (Amersham, RPN12).

Quantitative analysis of radioautograms. A computer image analysis system (IMSTAR) was used to determine the optical densities (OD) of the radioautograms from a variable gray scale. The program yielded an average integrated OD per $\mathrm{mm}^{2}$ for a selected area $\left(\mathrm{mm}^{2}\right)$ of interest. Measurements from radioautograms of the tissue transfer were made in well-defined anatomical regions corresponding to the TH-positive somatic area of the LC previously delineated on the adjacent section processed by TH immunohistochemistry (PND14, PND21, PND30, and PND42) or Nissl staining (PND4 and PND10). The contribution of the background was measured from section transfers incubated without anti-TH antibody, and the corresponding OD was systematically substracted from every measure.

One unit of TH (UTH) was defined as the mean TH protein content of $10 \mu \mathrm{g}$ of adult rat adrenal gland. The number of UTH contained in $1 \mu \mathrm{l}$ of each standard was known. The linear relationship between the UTH contained in one $\mathrm{mm}^{2}$ of each deposited standard and the corresponding mean integrated OD per $\mathrm{mm}^{2}$ enabled us to convert the densitometric measurement of tissue transfers radioautograms into UTH/ $\mathrm{mm}^{2}$. The surface $\left(\mathrm{mm}^{2}\right)$ of the measured areas had been determined to calculate the number of UTH contained in the region of interest.

Expression of the results. The tissue transfer from different rats at each developmental stage were initially set in a defined anatomical register. At PND42, the first rostral anatomical level on the caudorostral extent of the LC (level 11) corresponded to interaural coronal coordinate $-0.72 \mathrm{~mm}$ referring to the stereotaxic atlas of Paxinos and Watson (1986). For each section, the volume $\mathrm{V}$ of the transferred region of
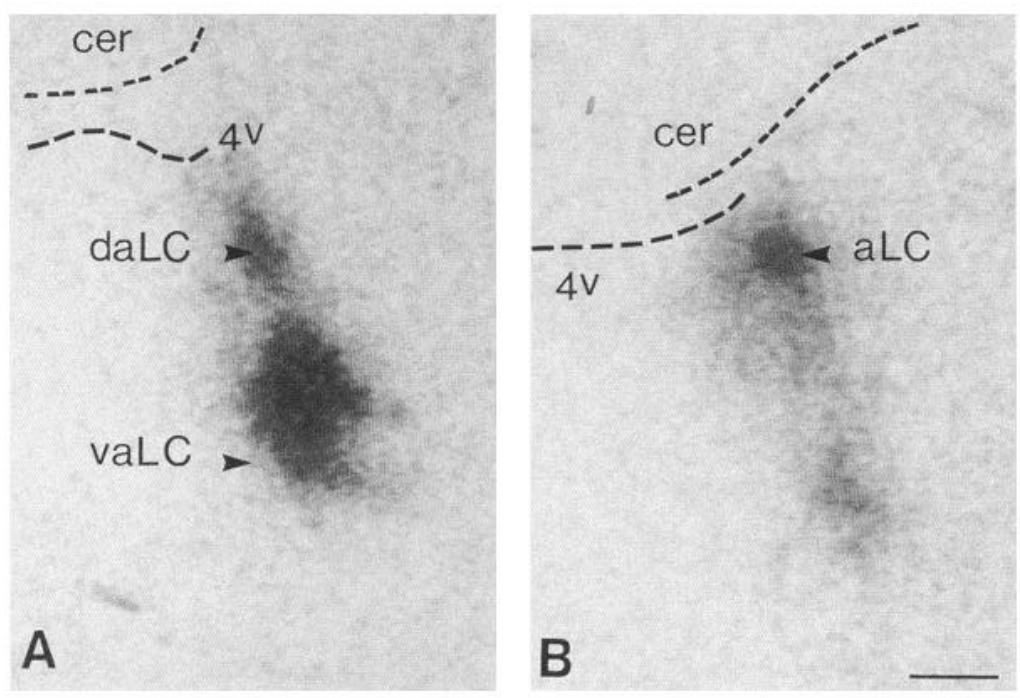

Figure 1. Radioautograms obtained from $10-\mu \mathrm{m}$-thick rat brain coronal sections referring to the first anatomical level of the anterior region of the $\mathrm{LC}$ (level 11 on the caudorostral extent of the structure). Total brain proteins of these sections were transferred onto nitrocellulose filters that were incubated with monoclonal anti-tyrosine hydroxylase (TH) antibody. This antibody was recognized by the ${ }^{125}$ I-labeled protein A. Two different developmental stages are shown: PND4 $(A)$ and PND42 $(B)$. The localization of surrounding anatomical landmarks is represented using the superimposition of the radioautographic images and the adjacent Nisslstained sections. $a L C$, anterior $\mathrm{LC}$; $c e r$, cerebellum; $d a L C$, dorsal anterior $L C$; $v a L C$, ventral anterior $L C ; 4 v$, fourth ventricle. Scale bar, $300 \mu \mathrm{m}$. 
PND4

$\square$ pLC daLC QvaLC
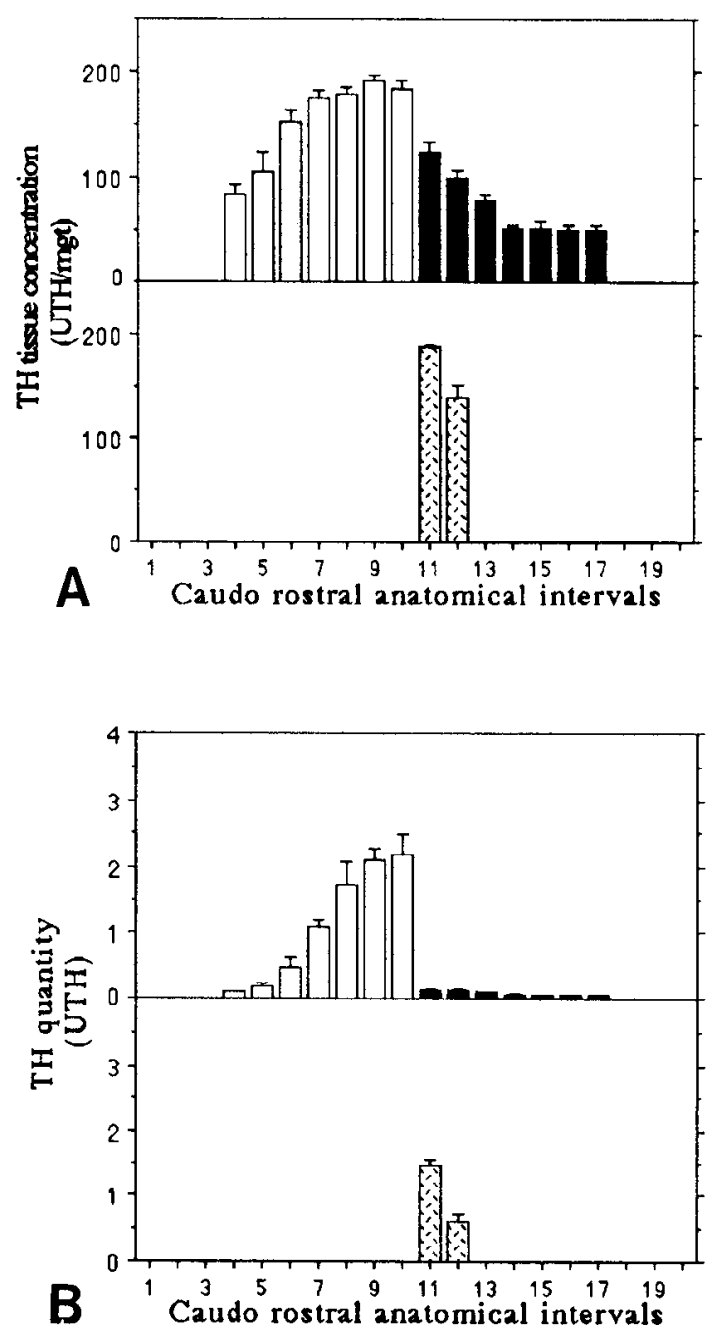

\begin{tabular}{ccccc}
\hline PND4 & pLC & daLC & vaLC & total LC \\
\hline $\begin{array}{c}\text { TH tissue } \\
\text { concentration } \\
\text { (UTH/mgt) }\end{array}$ & $\begin{array}{c}160.88 \\
\pm 4.83\end{array}$ & $\begin{array}{l}76.92 \\
\pm 3.49\end{array}$ & $\begin{array}{c}163.79 \\
\pm 6.67\end{array}$ & $\begin{array}{c}125.91 \\
\pm 3.18\end{array}$ \\
$\begin{array}{c}\text { TH quantity } \\
\text { (UTH) }\end{array}$ & $\begin{array}{c}7.37 \\
\pm 0.63\end{array}$ & $\begin{array}{c}0.53 \\
\pm 0.06\end{array}$ & $\begin{array}{c}2.08 \\
\pm 0.09\end{array}$ & $\begin{array}{c}9.98 \\
\pm 0.59\end{array}$ \\
\hline
\end{tabular}

C

Figure 2
PND10

$\square$ pLC $\square_{\text {daLC }}$ घvaLC
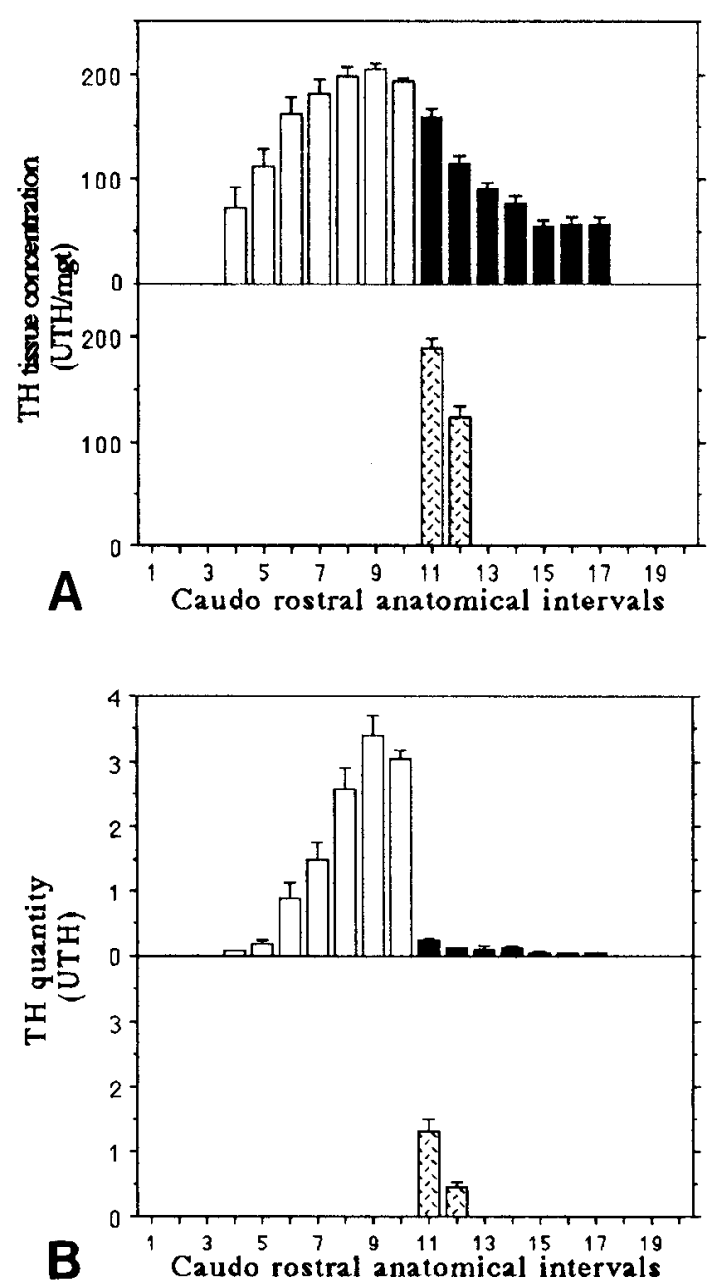

\begin{tabular}{|c|c|c|c|c|}
\hline PND10 & pLC & daLC & vaLC & total LC \\
\hline $\begin{array}{l}\text { TH tiseue } \\
\text { concentration } \\
\text { (UTH/mgt) }\end{array}$ & $\begin{array}{r}171.30 \\
\pm 10.60\end{array}$ & $\begin{array}{l}89.74 \\
\pm 6.79\end{array}$ & $\begin{array}{l}157.60 \\
\pm 9.34\end{array}$ & $\begin{array}{r}131.74 \\
\pm 4.53\end{array}$ \\
\hline $\begin{array}{l}\text { TH quantity } \\
\text { (UTH) }\end{array}$ & $\begin{array}{c}11.39 \\
\pm 0.66 \\
(81.9 \%)\end{array}$ & $\begin{array}{c}0.76 \\
\pm 0.06 \\
(5.5 \%)\end{array}$ & $\begin{array}{c}1.76 \\
\pm 0.25 \\
(12.6 \%)\end{array}$ & $\begin{array}{r}13.91 \\
\pm 0.57 \\
(100 \%)\end{array}$ \\
\hline
\end{tabular}

Figure 3.

Figures 2-7. $A$ and $B$, Distribution of the TH tissue concentration $(A)$ and the TH quantity $(B)$ along the caudorostral extent of each of the subregions of the LC somatic area: pLC, daLC or aLC and vaLC. Each bar represents the mean + SEM $(n=5-6)$ of these parameters determined in $80 \mu \mathrm{m}$ anatomical intervals. $C$, Mean TH tissue concentration and the quantity of TH in the total LC and its subdivisions. Results are expressed as the mean \pm SEM of the parameters. The percentage of the quantity of TH in each subdivision versus the value obtained in the total LC is reported. $D$ (Figs. 4-7), Correlation between the quantities of TH and the number of TH-immunoreactive cell bodies. TH protein quantities were calculated at intervals of $80 \mu \mathrm{m}$ along the caudorostral extent of the structure and the corresponding number of TH-immunoreactive perikarya was estimated from the postfixed adjacent section after immunocytochemical detection (Bezin et al., 1994). This correlation was established beyond PND10 when it was possible to process TH immunohistochemistry on postfixed sections obtained from fresh-frozen brains. 
PND14

$\square p L C \quad \square_{\text {dalC }}$ QvalC
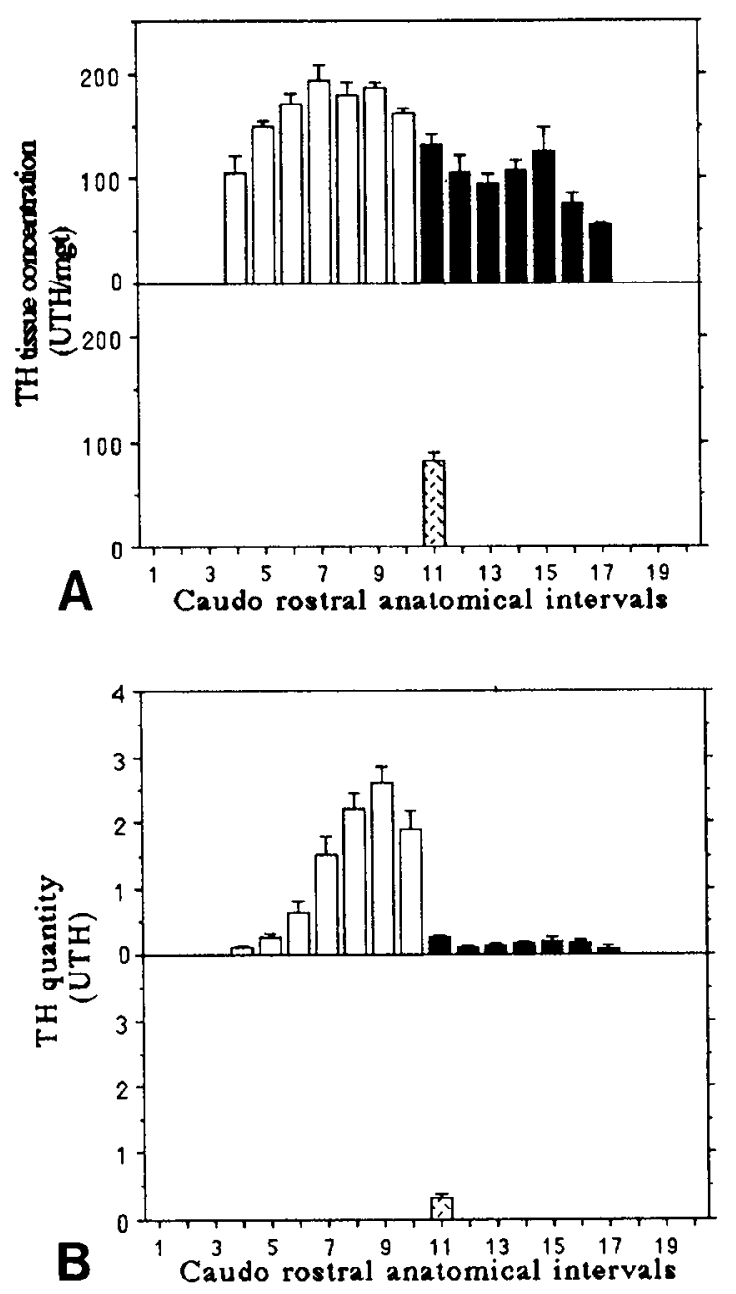

\begin{tabular}{ccccc}
\hline PND14 & pLC & daLC & valC & total LC \\
\hline $\begin{array}{c}\text { TH tiseuse } \\
\text { concentration } \\
\text { (UTH/mgt) }\end{array}$ & $\begin{array}{c}164.5 \\
\pm 5.27\end{array}$ & $\begin{array}{c}101.89 \\
\pm 10.08\end{array}$ & $\begin{array}{c}81.75 \\
\pm 8.91\end{array}$ & $\begin{array}{c}132.44 \\
\pm 5.86\end{array}$ \\
$\begin{array}{c}\text { TH quantity } \\
\text { (UTH) }\end{array}$ & $\begin{array}{c}9.28 \\
\pm 0.97\end{array}$ & $\begin{array}{c}0.91 \\
\pm 0.16\end{array}$ & $\begin{array}{c}0.31 \\
\pm 0.06\end{array}$ & $\begin{array}{c}10.5 \\
\pm 0.94\end{array}$ \\
& $(88.4 \%)$ & $(8.7 \%)$ & $(2.9 \%)$ & $(100 \%)$ \\
\hline
\end{tabular}

C

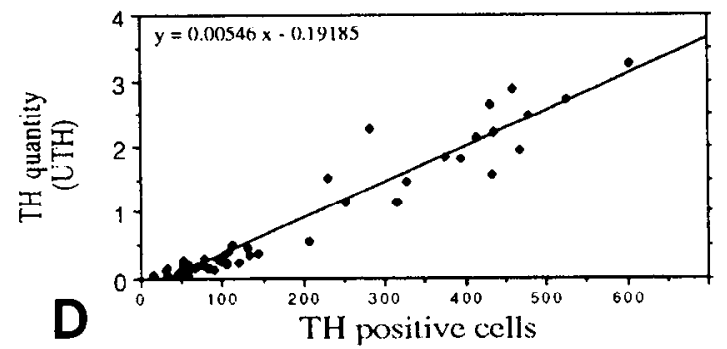

Figure 4.
PND21
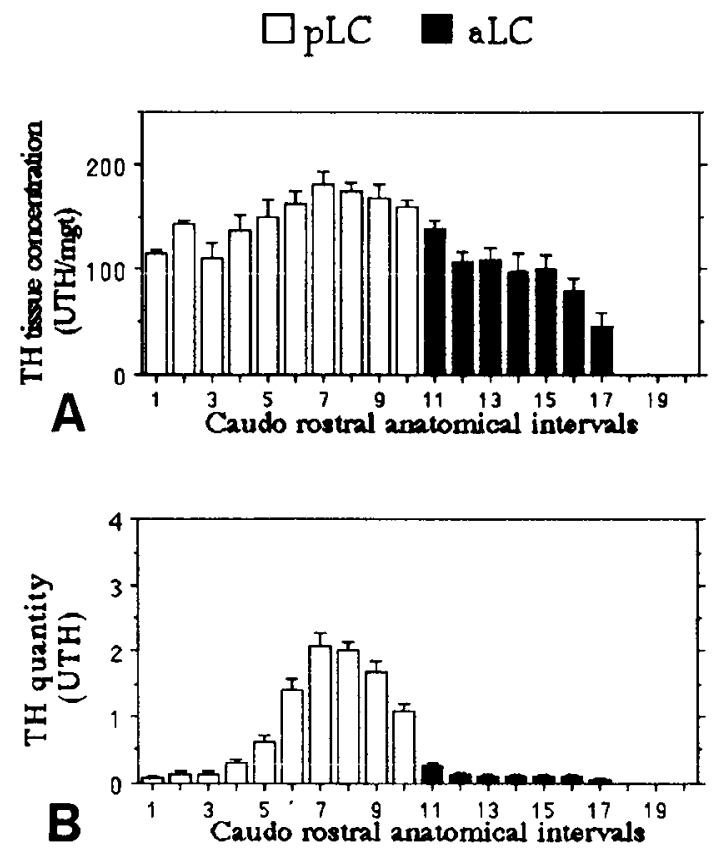

\begin{tabular}{|c|c|c|c|}
\hline PND21 & PLC & aLC & total LC \\
\hline $\begin{array}{l}\text { TH tissue } \\
\text { concentration } \\
\text { (UTH/mgt)" }\end{array}$ & $\begin{array}{l}153.70 \\
\pm 9.55\end{array}$ & $\begin{array}{r}106.40 \\
\pm 5.78\end{array}$ & $\begin{array}{r}136.67 \\
\pm 9.14\end{array}$ \\
\hline $\begin{array}{l}\text { TH quantity } \\
\text { (UTH) }\end{array}$ & $\begin{array}{c}9.34 \\
\pm 0.85 \\
(92.7 \%)\end{array}$ & $\begin{array}{c}0.74 \\
\pm 0.10 \\
(7.3 \%)\end{array}$ & $\begin{array}{c}10.08 \\
\pm 0.81 \\
(100 \%)\end{array}$ \\
\hline
\end{tabular}

C

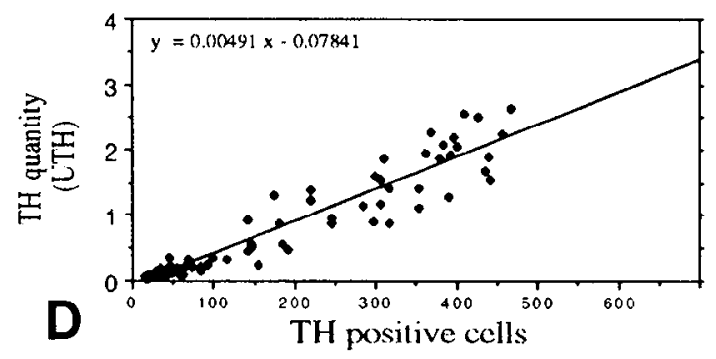

Figure 5.

interest was calculated $\left[V=S \cdot t, \mathrm{~mm}^{3}\right.$; where $S\left(\mathrm{~mm}^{2}\right)$ is the area in which the OD measure was made and $t$ the thickness of the section]. From the quantity of TH ( $Q$, unit of TH) measured in this area, the tissue concentration of TH (TC) was calculated ( $T C=Q / V$, unit of TH/ $\mathrm{mg}$ of tissue (mgt), $1 \mathrm{mgt}=1 \mathrm{~mm}^{3}$ ).

The results were expressed as the caudorostral distribution of the mean + SEM of the TH tissue concentration and the TH quantity estimated in $80 \mu \mathrm{m}$ intervals from values corresponding to $10-\mu \mathrm{m}$-thick sections.

The mean + SEM of the TH tissue concentration and the mean + SEM of the total TH quantity in the whole structure and in each one of its subregions were also calculated by adding values estimated all along the caudorostral extent of the structure (or part of it). Statistical analysis of these results was performed using a one-way analysis of variance (ANOVA I), where $n$ is the number of animals, to compare 


\section{PND30}

\section{$\square$ pLC $\square$ aLC}
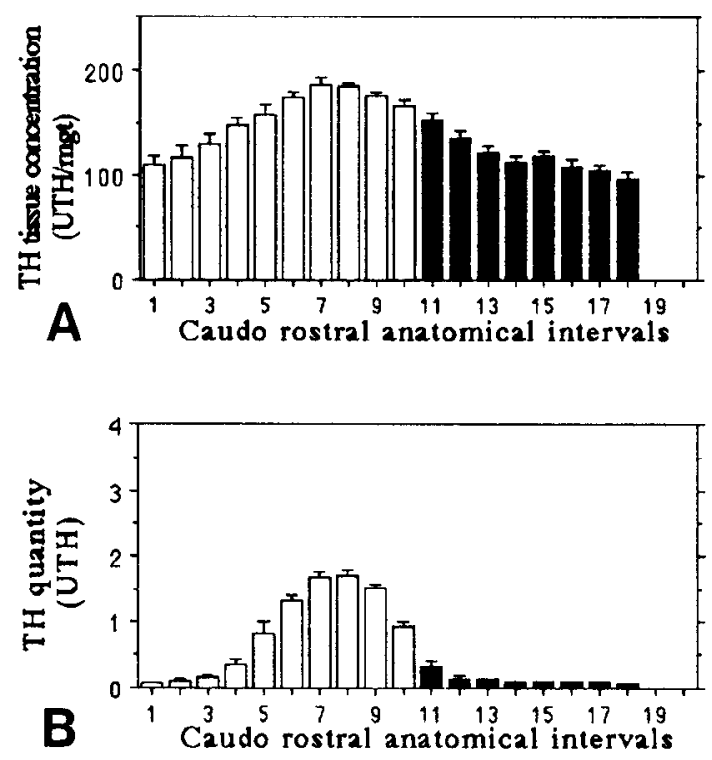

\begin{tabular}{|c|c|c|c|}
\hline PND30 & PLC & $a L C$ & total LC \\
\hline $\begin{array}{c}\text { TH tiasue } \\
\text { concentration } \\
\text { (UTH/mgt) }\end{array}$ & $\begin{array}{c}158.38 \\
\pm 2.9\end{array}$ & $\begin{array}{l}119.43 \\
\pm 3.93\end{array}$ & $\begin{array}{r}140.83 \\
\pm 1.70\end{array}$ \\
\hline $\begin{array}{l}\text { TH quantity } \\
\text { (UTH) }\end{array}$ & $\begin{array}{c}8.62 \\
\pm 0.40 \\
(89.2 \%) \\
\end{array}$ & $\begin{array}{c}1.04 \\
\pm 0.13 \\
(10.8 \%)\end{array}$ & $\begin{array}{c}9.66 \\
\pm 0.38 \\
(100 \%)\end{array}$ \\
\hline
\end{tabular}

C

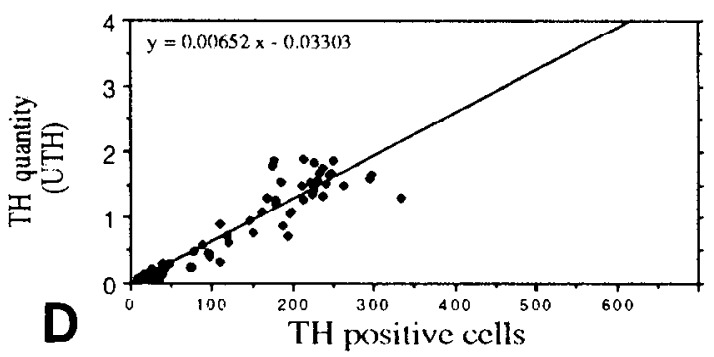

Figure 6.

the effect of postnatal development on these two parameters. The comparison between any two developmental stages was made in each of the subregions of the LC using the $95 \%$ Bonferroni simultaneous confidence intervals. An ANOVA I was also used to statistically test, in each age group, the effect of the caudorostral level on each parameter value ( $n$ was the number of all sections analyzed in each group).

\section{Results}

Anatomical identification of the TH immunoradioautographic signal

At each developmental stage, the TH radioautographic detection was very highly specific since the superimposition of the radioautograms with the adjacent Nissl-stained sections allowed
PND42

$\square \mathrm{pLC} \mathbf{a}_{\mathrm{aLC}}$
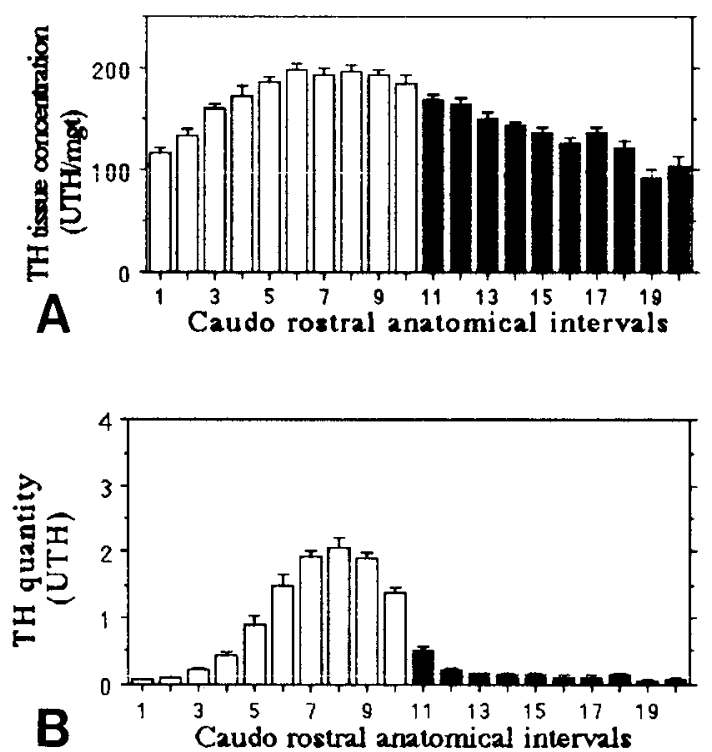

\begin{tabular}{cccc}
\hline PND42 & pLC & aLC & total LC \\
\hline $\begin{array}{c}\text { TH tiasue } \\
\text { concentration } \\
\text { (UTH/mgt) }\end{array}$ & $\begin{array}{c}173.70 \\
\pm 4.58\end{array}$ & $\begin{array}{c}138.91 \\
\pm 2.13\end{array}$ & $\begin{array}{c}157.45 \\
\pm 2.36\end{array}$ \\
$\begin{array}{c}\text { TH quantity } \\
\text { (UTH) }\end{array}$ & 10.46 & 1.48 & 11.94 \\
& $\begin{array}{c} \pm .38 \\
(87.6 \%)\end{array}$ & $\begin{array}{c} \pm 0.08 \\
(12.4 \%)\end{array}$ & $\begin{array}{c} \pm 0.45 \\
(100 \%)\end{array}$ \\
\hline
\end{tabular}

C

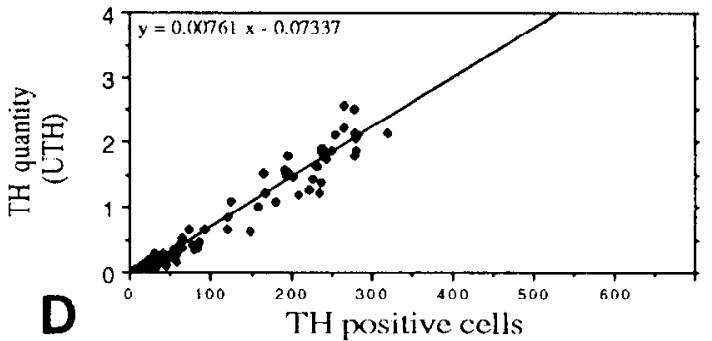

Figure 7.

to identify the reaction in the noradrenergic nucleus LC. TH protein stained by the immunoradioautographic method after transfer of coronal brain sections onto nitrocellulose filters is shown at two different postnatal stages: PND4 (Fig. 1A) and PND42 (Fig. 1B).

From PND4 to PND14, it was possible to observe, with the anatomical resolution of this method, the distinct division of the radioautograms into dorsal and ventral parts in the middle of the caudo rostral extent of the LC (level 11, Figs. 2-4).

In this study, and for all age groups, the anatomical level 11 represents the first rostral plane of the LC on its caudorostral axis. At PND42, it corresponds to IA: $-0.72 \mathrm{~mm}$ in Paxinos and Watson's stereotaxic atlas (1986). 
TH tissue concentralion (UTH/mgt)

\section{total LC}

pLC

daLC

vaLC
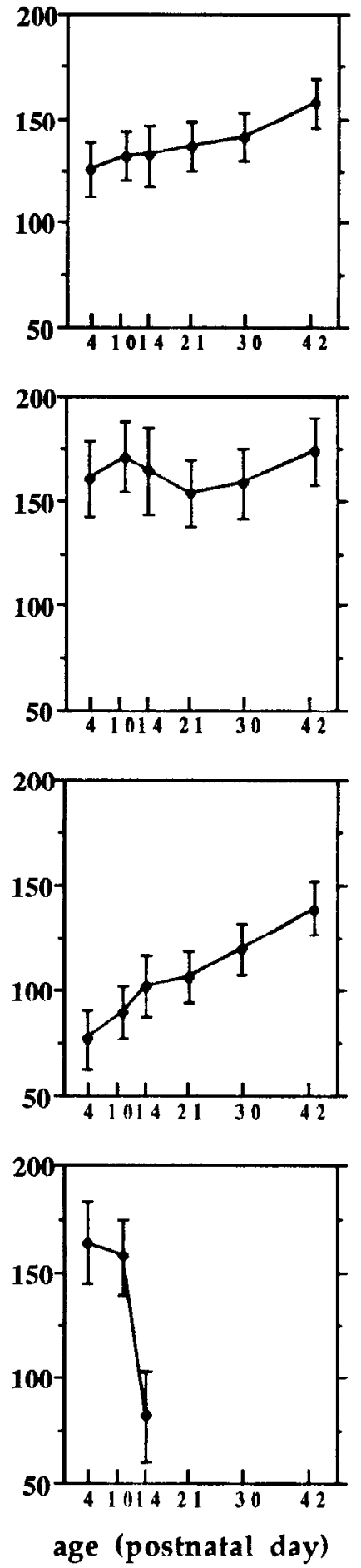

TH quantity (UTH)
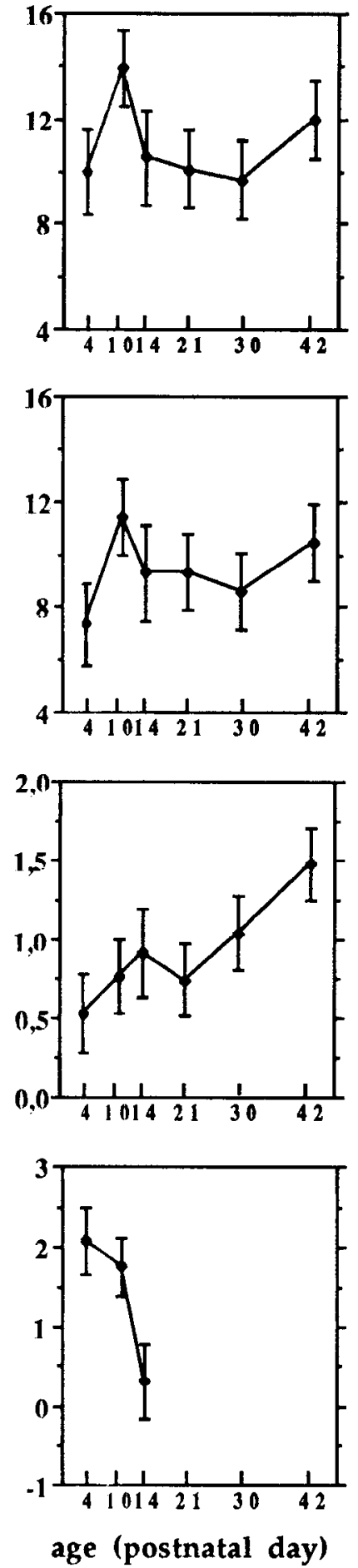

Figure 8. Statistical analysis of the postnatal evolution of the biochemical parameters defining the phenotypic characterization of TH expression, quantitatively determined in the somatic area of the total LC and each of its subregions. Results are expressed as the mean + the $95 \%$ Bonferroni confidence interval for each age. The effect of development on these parameters is studied using a one-way analysis of variance. Significant difference $(p<$ 0.05 ) between two age groups can be considered when their respective $95 \%$ Bonferroni confidence intervals do not overlap. For the total $L C$, the postnatal development affects ' $\mathrm{TH}$ tissue concentration $(p<0.004)$ and the quantity of TH $(p<0.0001)$. For the $p L C$, the postnatal development affects the quantity of TH $(p<0.003)$ but does not affect TH tissue concentration $(p<0.327)$. For the daLC, from PND4 to PND14 and from PND21 to PND42, the values for the daLC and aLC are reported, respectively. Postnatal development affects TH tissue concentration ( $p<$ $0.0001)$ and the quantity of TH ( $p<$ $0.0001)$. For the vaLC, postnatal development affects $\mathrm{TH}$ tissue concentration $(p<0.0001)$ and the quantity of TH $(p<0.0001)$.
Postnatal evolution of the phenotypic characteristics of $T H$ protein

The biochemical parameters characterizing the TH expression in the LC somatic area were examined along the caudorostral extent of the structure at six postnatal stages: PND4 (Fig. 2), PND10 (Fig. 3), PND14 (Fig. 4), PND21 (Fig. 5), PND30 (Fig.
6), and PND42 (Fig. 7). The TH tissue concentration and the TH quantity were evaluated at intervals of $80 \mu \mathrm{m}$, exactly within the topological space delineated by the TH-cxpressing cell bodies, in different subdivisions of the LC: posterior LC (pLC), dorsal anterior LC (daLC) or anterior LC (aLC) and ventral anterior LC (vaLC) when it was detectable. 


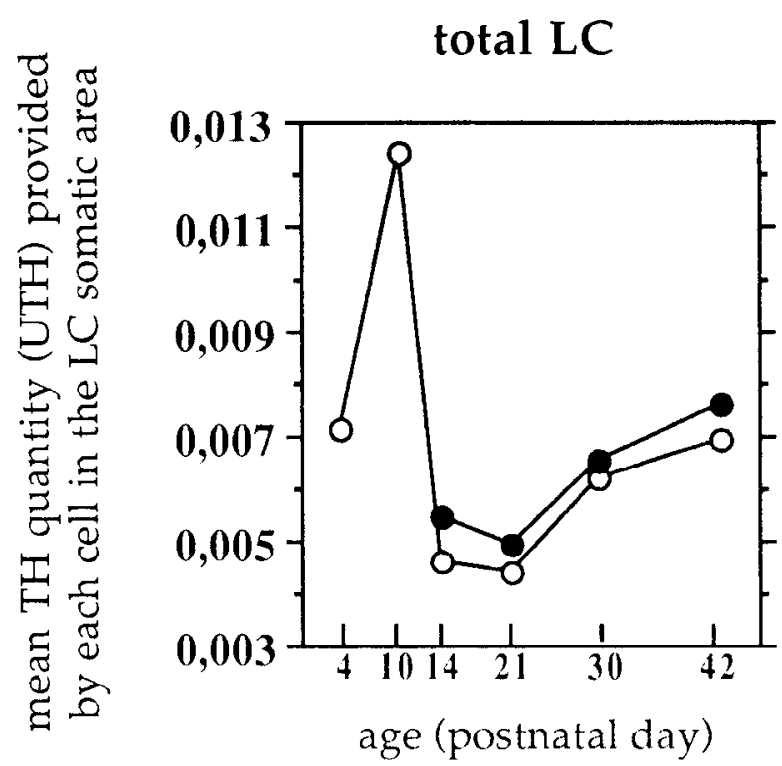

Figure 9. Postnatal development of the mean TH quantity provided by each cell in the TH-positive somatic area of the total LC. The postnatal evolution of the mean cell contribution to the quantity of $\mathrm{TH}$ measured in the somatic area of the $L C$ is represented in two different ways. In the first (solid circles), it is reported as the slope of the correlation curve between the quantities of TH and the number of TH-immunoreactive cell bodies evaluated in each slice along the caudorostral extent of the LC. Each slope is significantly different from the others $(p<$ 0.0001 , Student's $t$ test). In the second (open circles), this parameter is reported as the ratio of the mean quantity of $\mathrm{TH}$ in the total $\mathrm{LC}$ versus the mean number of TH-immunoreactive cell bodies in the total LC. At PND4 and PND10, different groups of animals were used for the quantification of $\mathrm{TH}$ and the enumeration of the TH-positive perikarya. Beyond PND10, both parameters were obtained on the same animals Note the similarity in the evolution of the two different means of calculation of the parameter considered. The number of TH-immunoreactive cell bodies in the total LC was reported in the preceding study (Bezin et al., 1994) for each postnatal stage studied. It equaled 1432, $1116,2298,2297,1563$, and 1728 TH-positive perikarya at PND4, PND10, PND14, PND21, PND30, and PND42, respectively.

\section{TH tissue concentration}

At each developmental stage, the TH tissue concentration was distributed ( $p<0.0001$, ANOVA I, $66<$ number of sections $<113$ ) along the caudorostral axis of the structure, though the differences in this parameter between the posterior and the dorsal anterior subdivisions of the LC were reducing from PND4 to PND42 (Figs. $2 A-7 A$ ).

The mean tissue concentration of TH was always higher in the pLC than in the daLC and aLC whereas it was the same in the pLC and the vaLC at PND4 and PND10 (Figs. $2 C-7 C, 8$ ).

The mean tissue concentration of $\mathrm{TH}$ remained constant during the postnatal period within the $\mathrm{pLC}$ whereas it progressively increased within the daLC (Fig. 8).

\section{TH quantity}

At each developmental stage, the TH quantity was strongly distributed $(p<0.0001$, ANOVA I, $66<$ number of sections $<113$ ) along the caudorostral extent of the structure (Figs. $2 B$ $7 B$ ). The pLC contained $73.9-92.7 \%$ of the amount of the TH evaluated in the total LC. This validated the division of the LC into a large posterior and a small anterior subregions.

The dosage of TH revealed a greater TH quantity at PND10 than at the other stages, with the exception of PND42 (Fig. 8). The highest values of TH quantity were observed at PND10 at levels $8-10$ (Fig. $3 B$ ) as well as at PND14 but only at level 9 (Fig. 4B).

\section{Mean cell contribution to the TH quantity of the $L C$}

A highly significant correlation was observed between the number of TH-immunopositive perikarya counted at every anatomical level ( $x$; results reported in Bezin et al., 1994) and the TH quantity measured within the somatic area on the adjacent section (y). From PND14 through PND42 the equation of the curve ( $n$. number of sections considered) and significance of the linear regression (ANOVA I) are reported; PND14: $y=0.00546 x-$ $0.19815, n=65, R^{2}=0.932, p<0.0001$ (Fig. 4D); PND21: $y$ $=0.00491 x-0.07841, n=97, R^{2}=0.901, p<0.0001$ (Fig. 5D); PND30: $y=0.00652 x-0.03303, n=104, R^{2}=0.90, p$ $<0.0001$ (Fig. 6D); PND42: $y=0.00761 x-0.07337 ; n-113$, $R^{2}=0.954, p<0.0001$ (Fig. $7 D$ ).

The slope of these correlation curves was considered as the mean TH quantity provided by each cell in the somatic area and it was estimated in the total LC at PND14, PND21, PND30, and PND42 as $0.00546 \mathrm{UTH} /$ cell, $0.00491 \mathrm{UTH} /$ cell, 0.00652 $\mathrm{UTH} /$ cell, and $0.00761 \mathrm{UTH} /$ cell, respectively. Each slope was significantly different from the others $(p<0.0001$, Student's $t$ test).

The TH quantity brought by each cell exhibited a postnatal evolution with a peak at PND10 largely detached from the values calculated at the other stages (Fig. 9).

\section{Discussion}

We aimed to state accurately the biochemical parameters defining the phenotypic characterization of $\mathrm{TH}$ expression in the LC at each studied developmental stage. The TII tissue concentration and the $\mathrm{TH}$ quantity were evaluated with precision in the spaces delineated by the cells expressing TH protein. This ontogenic followup of the $\mathrm{TH}$-expressed protein revealed invariant and variant phenotypic characteristics of TH expression in the somatic area of the LC.

The quantitative radioautographic dosage of TH protein content after direct transfer of total proteins from unfixed brain sections ( $10 \mu \mathrm{m}$ thick) onto nitrocellulose filters constituted a sensitive method supported by a high anatomical resolution. It was possible to precisely delimit and then restrict the measurements to the somatic area of the LC that were very impregnated on radioautographic images. The anatomical resolution of the method was first illustrated by the close superimposition of the dense radioautographic images and the catecholaminergic elements stained on the adjacent section after TH-immunohistochemistry. Moreover, the anatomical dichotomy of the anterior region of the $\mathrm{LC}$ between a dorsal and a ventral subdivision at the early stages, first identified in the preceding immunohistochemical study (Bezin et al., 1994), has also been observed on radioautographic images. Finally, the caudorostral extent of the radioautographic detection of $\mathrm{TH}$ protein was similar to the extent determined from the previous immunohistochemical study. At each developmental stage the efficiency of the direct transfer of total brain proteins was verified. In all cases, the amount of proteins transferred from frozen unfixed brain sections of 5-30 $\mu \mathrm{m}$ thick was directly proportional to the slice thickness, as already demonstrated by Weissmann et al. (1989), and exhibited a global recovery of $90 \%$ of total brain proteins at the end of the incubation period necessary for the specific 
detection of TH (data not shown). With the exception of PND4 and PND10, it was possible to determine the TH content and the number of TH-expressing cells on adjacent sections. A highly linear correlation between these two parameters was demonstrated from PND14 and beyond, the intercept of the correlation curves being almost zero. Such results suggest that the origin of TH protein measured in the somatic area in one interval was exclusively from coeruleal neurons (perikarya and their very proximal dendrites) of the considered interval. We then estimated the mean TH quantity provided by each cell in the somatic area (or mean TH quantity per cell for simplification), which corresponded to the slope of these correlation curves. At PND4 and PND10, methodological limits prevented the determination of the TH content and the enumeration of TH-expressing cells from adjacent sections; each of these parameters was obtained from distinct animals. The mean TH quantity per cell was estimated by a second method: the mean TH quantity in the total LC was divided by the mean number of TH-expressing cells in the total LC. The two methods gave similar evolution of the mean TH quantity per cell from PND14 to PND42. So, the evolution of the mean cell contribution to the total LC TH content could be observed from PND4 to PND42.

The examination of $\mathrm{TH}$-expressed protein parameters within the rat LC during its postnatal development revealed the invariability of some phenotypic characteristics of TH expression in this structure.

Our results demonstrate that the mean value of the TH tissue concentration and the mean TH quantity in the pLC are always greater than the one measured in the daLC during postnatal development. So, at each developmental stage, the caudorostral distributions of the TH tissue concentration and the TH quantity should make for an objective separation of the LC into a posterior and an anterior subregion, as already observed for cellular parameters: the number of TH-expressing perikarya and the volume delineated by these perikarya (Bezin et al., 1994).

The TH content measured within the compartment of perikarya and their very proximal dendrites resulted from the tissue concentration of TH and the volume of this compartment. The tissue concentration of $\mathrm{TH}$ and the volume delineated by the TH-expressing cell bodies remained quite stable during the postnatal development. Thus the TH quantity exhibited little agerelated differences, excepting the transient peak observed at PND10. However, the evolution of the TH quantity evaluated in this study did not correspond to the progressive increase of TH quantity reported in the LC using a Western blot procedure (Zyzek et al., 1990). This could be as a result of methodological differences. The Western blot analysis was realized from LC tissue punches that included the perikarya and most of the surrounding neuropil. There might therefore be a different evolution of TH content between the compartment formed by the perikarya and their proximal dendrites on the one hand, and the compartment formed by the surrounding neuropil on the other. We can reasonably hypothesize that TH quantity in this latter compartment would progressively increase during the postnatal period.

The tissue concentration of TH within the $\mathrm{pLC}$ remained constant during the postnatal development. Concerning the vaLC, the TH tissue concentration at PND4 and PND10 was close to the value observed in the respective pLC. We have also demonstrated that the volume of the anatomical entity, which may be composed by the $\mathrm{pLC}$ and the vaLC, remained constant during postnatal development (Bezin et al., 1994). So, in this probable anatomical entity, invariant developmental phenotypic characteristics of $\mathrm{TH}$ expression could be represented by the tissue concentration of TH and the volume delineated by the TH-expressing cell bodies.

We have, nevertheless, observed variant developmental phenotypic characteristics of $\mathrm{TH}$ expression within the $\mathrm{LC}$ during the postnatal period. The tissue concentration of TH did not follow the same postnatal evolution in the different subdivisions of the LC, which gave further evidence for the heterogeneity of the structure. An age-related reducing of the mean TH tissue concentration differences between the pLC and the daLC was observed. It resulted to an age-related increase in this parameter in the daLC whereas TH tissue concentration remained stable in the pLC. The steady state of the tissue concentration of TH would have been established early in the pLC (bcfore PND4), whereas the daLC would reach it later (beyond PND42). Such hypothesis about the somatotopic organization of the LC neurons have been advanced from the analysis of the target area organization of this structure (Loughlin et al., 1986), from the TH expression in basal conditions (Debure et al., 1992), and from responses to pharmacological treatment (Debure et al., 1992; Schmitt et al., 1993). Intensive variations of the mean TH quantity per cell have been observed during the early stages of the postnatal development. The more numerous the THexpressing cells during postnatal development, the less each one contributed to the total amount of TH protein in the LC. The highest amplitude of variation occurred during the first 2 weeks concomitant with the deep topological reorganization of the caeruleal TH-positive cell bodies (Sievers et al., 1981; Bezin et al., 1994).

We have demonstrated that invariant and variant phenotypic characteristics are involved in the developmental evolution of the TH expression in the LC. In this structure, plasticity of both the number of TH-expressing cells and TH quantity per cell have been revealed during the postnatal ontogeny. However, the total volume of the structure and the mean TH tissue concentration were stable during the same period. These observations fostered the interest to hypothesize about a possible link between these phenomena.

All measurements were realized in steady-state conditions that represent a balance between the mechanisms involved in the synthesis and in the disappearance of the protein. The modifications in the mean TH quantity per cell may be explained in part by alterations in the rate of synthesis of the protein. This rate could be enhanced between PND4 and PND10; the evolution of TH mRNA expression needs to be studied to test this hypothesis. Beyond PND10, the dramatic decrease in the mean TH quantity per cell could correspond to increases in the disappearance rate of the protein, which would be too fast to be balanced by the synthesis mechanisms. The transport of the protein either in the terminal fields, in the dendritic compartment or both of them could explain such a decrease. In this way, studies in the olfactory bulb have reported a high increase in the density of the noradrenergic innervation from the LC neurons beyond the first postnatal week (McLean and Shipley, 1991).

Another hypothesis is possible. The mean TH quantity per cell could be regulated to keep constant the TH tissue concentration in the somatic area constant. As TH activity in the pons was reported to reach the adult value at PND14 (Coyle and Axelrod, 1972), the concomitant stabilization of these two parameters could have a functional importance in the develop- 
mental steps of young rats. It is interesting to note that the autoinhibitory synaptic mechanisms mediated by the $\alpha 2$ adrenoceptors were established beyond PND15 in the LC (Kimura and Nakamura, 1987). The end of the second postnatal week would represent a critical period in the establishment of the functions of the LC.

We have demonstrated in this work that the establishment of $\mathrm{TH}$ expression in the $\mathrm{LC}$ exhibited variant and invariant phenotypic characteristics during postnatal development. A dichotomy of the structure into a postcrior and an antcrior subregion was confirmed by differences in the kinetics of establishment of the TH protein expression. A plasticity of the quantity of TH per cell was revealed during this period. Because the number of TH-expressing cell bodies was concomitantly following an opposite evolution to the one observed for the $\mathrm{TH}$ quantity per cell, TH tissue concentration remained quite stable in the space that containing these perikarya. Further studies are, however, necessary to apprehend the postnatal evolution of the phenotypic characteristics of TH expression in the dendritic compartment of coeruleal neurons, which are known to extend considerable distances beyond the cellular limits of the nucleus at the adult stage (Swanson, 1976).

\section{References}

Bezin L, Marcel D, Debure LI, Ginovart N, Rousset C, Pujol J-F, Weissmann D (1994) Postnatal development of the tyrosine hydroxylase-containing cell population within rat locus coeruleus: topological organization and phenotypic plasticity. J Neurosci 14:74867501 .

Coyle JT, Axelrod J (1972) Tyrosine hydroxylase in the rat brain: developmental characteristics. J Neurochem 19:1117-1123.
Debure LI, Moyse E, Fevre-Montange M, Hardin H, Belin MF, Rousset C, Pujol JF, Weissmann D (1992) Somatotopic organization of tyrosine hydroxylase expression in the rat locus coeruleus: long term effect of RU24722. Brain Res 581:19-32.

Kimura F, Nakamura S (1987) Postnatal evolution of $\alpha$-adrenoceptormediated autoinhibition in the locus coeruleus. Dev Brain Res 35: 21-26.

Levitt M, Spector S, Sjoersma A, Udenfriend S (1965) Elucidation of the rate-limiting step in the norepinephrine biosynthesis in the perfused guinea-pig heart. J Pharmacol Exp Ther 148:1-8.

Loughlin SE, Foote SL, Bloom FE (1986) Efferent projections of nuclcus locus coeruleus: topographic organization of cells of origin demonstrated by three-dimensional reconstruction. Neuroscience 18:291306.

McLean JH, Shipley MT (1991) Postnatal development of the noradrenergic projection from locus coeruleus to the olfactory bulb in the rat. J Comp Neurol 304:467-477.

Nagatsu T, Levitt M, Udenfriend S (1964) Tyrosine hydroxylase. The initial step in norepinephrine synthesis. J Biol Chem 239:2910-2917.

Schmitt P, Reny-Palasse V, Bourde O, Garcia C, Pujol JF (1993) Further characterization of the long-term effect of RU24722 on tyrosine hydroxylase in the rat locus coeruleus. J Neurochem 61:1423-1429.

Sievers J, Lolova I, Jenner S, Klemm HP, Sievers H (1981) Morphological and biochemical studies on the ontogenesis of the nucleus locus coeruleus. Bibl Anat 19:52-130.

Swanson LW (1976) The locus coeruleus: a cytoarchitectonic, Golgi and immunohistochemical study in the albino rat. Brain Res 110:3956.

Weissmann D, Labatut R, Rousset C, Pujol JF (1989) Direct transfer into nitrocellulose and quantitative radioautographic anatomical determination of brain tyrosine hydroxylase protein concentration. $J$ Neurochem 53:793-799.

Zyzek E, Richard F, Bouilloux JP, Pujol JF (1990) Ontogeny of tyrosine hydroxylase concentration in locus coeruleus of newborn rats: long-term effects of RU24722. J Neurochem 55:849-853. 